\title{
Journal of Enterprise Information Management
}

Exploring the commercial value of social networks: Enhancing consumers' brand experience through Facebook pages

Hsin Chen Anastasia Papazafeiropoulou Ta-Kang Chen Yanqing Duan Hsiu-Wen Liu

\section{Article information:}

To cite this document:

Hsin Chen Anastasia Papazafeiropoulou Ta-Kang Chen Yanqing Duan Hsiu-Wen Liu , (2014),"Exploring the commercial value of social networks", Journal of Enterprise Information Management, Vol. 27 Iss 5 pp. 576 598

Permanent link to this document:

http://dx.doi.org/10.1108/JEIM-05-2013-0019

Downloaded on: 17 October 2014, At: 02:55 (PT)

References: this document contains references to 88 other documents.

To copy this document: permissions@emeraldinsight.com

The fulltext of this document has been downloaded 132 times since 2014*

\section{Users who downloaded this article also downloaded:}

Linnea Hansson, Anton Wrangmo, Klaus Solberg Søilen, (2013),"Optimal ways for companies to use

Facebook as a marketing channel", Journal of Information, Communication and Ethics in Society, Vol. 11 Iss 2 pp. $112-126$

Dr Angela Hausman, Sertan Kabadayi, Katherine Price, (2014),"Consumer - brand engagement on Facebook: liking and commenting behaviors", Journal of Research in Interactive Marketing, Vol. 8 Iss 3 pp. 203-223 http://dx.doi.org/10.1108/JRIM-12-2013-0081

Chechen Liao, Pui\#Lai To, Chuang\#Chun Liu, (2013),"A motivational model of blog usage", Online Information Review, Vol. 37 Iss 4 pp. 620-637

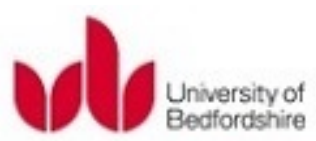

\section{Learning Resource}

Access to this document was granted through an Emerald subscription provided by 281408 []

\section{For Authors}

If you would like to write for this, or any other Emerald publication, then please use our Emerald for Authors service information about how to choose which publication to write for and submission guidelines are available for all. Please visit www. emeraldinsight. com/ authors for more information.

\section{About Emerald www.emeraldinsight.com}

Emerald is a global publisher linking research and practice to the benefit of society. The company manages a portfolio of more than 290 journals and over 2,350 books and book series volumes, as well as providing an extensive range of online products and additional customer resources and services.

Emerald is both COUNTER 4 and TRANSFER compliant. The organization is a partner of the Committee on Publication Ethics (COPE) and also works with Portico and the LOCKSS initiative for digital archive preservation. 
*Related content and download information correct at time of download. 
JEIM

27,5

576

Received 6 May 2013

Revised 26 July 2013

28 July 2013

Accepted 28 July 2013

\section{Exploring the commercial value of social networks}

\section{Enhancing consumers' brand experience through Facebook pages}

\author{
Hsin Chen \\ Department of Business Systems, University of Bedfordshire, Luton, UK \\ Anastasia Papazafeiropoulou \\ School of Information Systems, Computing \& Mathematics, \\ Brunel University, Uxbridge, UK \\ Ta-Kang Chen \\ Department of Business Administration, SooChow University, \\ Shulin District, New Taipei City, Taiwan \\ Yanqing Duan \\ Department of Business Systems, University of Bedfordshire, Luton, UK, and \\ Hsiu-Wen Liu \\ Department of Business Administration, SooChow University, \\ Taipei City, Taiwan
}

\begin{abstract}
Purpose - The purpose of this paper is to understand the factors which impact upon the consumers' willingness to utilise company Facebook pages and e-word-of mouth by proposing and testing a conceptual framework which is inspired by theories in marketing and information systems fields. The authors believe that only by applying both theories will provide a more complete understanding of the relationship between brand experience and Facebook. The research model attempts to illustrate the factors according to customers' intrinsic and extrinsic motivations and their impact on brand experience, brand Facebook page loyalty and e-word-of-mouth (E-WOM).

Design/methodology/approach - The authors adopted an online survey method for data collection. The subjects the authors used were Facebook users. The data were collected in Taiwan over spring 2011. The authors then used the structural equation model to analyse the data collected.

Findings - The findings suggest that users are influenced by the technical characterises of a brand Facebook page, such as ease of use and usefulness, which might be combated by attempting to reduce customer effort when accessing Facebook pages. The authors conclude that customer effort influenced brand experience and consequently loyalty to brand Facebook pages and E-WOM.

Research limitations/implications - The limitations of this study relate to the investigation of consumer perspectives in a specific geographical context and time frame.

Originality/value - The study's contributions are both theoretical and practical, as it offers new insights into brand experience attitudes in an online environment and useful insights to companies willing to market themselves on Facebook.

Keywords Marketing, Facebook, Virtual community, Extrinsic motivations, Intrinsic motivations Paper type Research paper
\end{abstract}

Journal of Enterprise Information Management

Vol. 27 No. 5, 2014

pp. 576-598

(C) Emerald Group Publishing Limited 1741-0398

DOI 10.1108/JEIM-05-2013-0019

\section{Introduction}

Facebook, a social web site, provides a platform for people to interact, communicate and share with one another, enhancing human connectivity and sociability (Nie, 2001). Facebook is the most visited web site in most countries around the globe and according 
to a survey conducted by the company itself, over 0.4 billion global users are active on the web site every month. More than 20 million people connect to pages every day and more than five billion pieces of content (event, news stories, blog posts, notes, photo albums, etc.) are shared each week (www.box.net/shared/24mkyggle9). The popularity of Facebook has attracted attention from the business world and inspired a wide range of marketing activities aimed at utilising the new platform. Facebook allows business users to create a custom page promoting their businesses. According to survey results produced by Pagemodo (www.pagemodo.com), having a Facebook page increases sales for small businesses and drives greater traffic to their web sites. Many businesses, especially small business owners, see Facebook as an easy way to develop marketing tools that can attract new customers and help them interact with existing ones. The survey results also show that there has been an increase in the number of companies adopting Facebook as a business tool. We are reaching a point where social media can be as much about business as it is about fun. There are many successful business pages on Facebook. For example, Pizza Hut's Facebook page contains an order form, making it easy for Facebook users to order a pizza. The Pringles Facebook page contains humorous video posts depicting people's experiences consuming their product which have proven popular with the public. The Victoria's Secret Facebook page contains a bikini builder, helping fans to find their perfect bikini after just a couple of clicks.

Although many companies are using the social network site and its fan pages to market their brands and products, limited academic research has been carried out to understand how to enhance consumers' brand experience through social network pages. For example, only limited studies have pointed out how the online community enhances brand equity by improving brand word-of-mouth (Adjei et al., 2009; McAlexander et al., 2002; Keller, 2001; Hoeffler and Keller, 2002; Dwyer et al., 2007). No research has discussed the benefits which brands would gain by interacting, communicating and sharing with their fans. Therefore, we consider that determining how to operate brand communities on Facebook, how to improve the relationship with customers through the Facebook page platform and the reasons affecting customers' intention to use the brand's Facebook pages are very important issues for companies. To do this, it is not only important to understand the factors driving people to use new technical media such as perceived ease of use and perceived usefulness, but also to understand from a marketing point of view (e.g. experience marketing). Experience marketing is not a new marketing concept, as Schmitt (1999) first proposed this concept in 1999. He points out that a brand is about more than correct price or correct value. It is also a correct experience by establishing contact with customers. Tsai (2005) argues that in order to improve customer experience, brands need to manage their media image, such as through interaction between media and customer. According to Barwise and Meehan's (2010), Facebook, as a very popular social network web site, could help brands to disseminate word of mouth, whether positive or negative, with amazing speed. Therefore, companies should provide their customers with positive experiences, such as: providing useful information or enabling customers to have conversations with the brand and other customers who interact with the brand online.

This study aims to understand the factors which impact upon the consumers' willingness to utilise company Facebook pages and e-word-of mouth by proposing and testing a conceptual framework which is inspired by theories in marketing and information systems fields. We believe that only by applying both theories will provide a more complete understanding of the relationship between brand experience and
Commercial value of social networks

577 
JEIM

27,5

578
Facebook. The research model attempts to illustrate the factors according to customers' intrinsic and extrinsic motivations and their impact on brand experience, brand Facebook page loyalty and e-word-of-mouth (E-WOM).

The paper will first provide a review of the relevant academic literature and development of the hypothesis. Next, it will provide an overview of the research methods, after which findings will be presented and discussed. The last section of the paper will outline conclusions, limitations and suggestions for further research.

\section{Literature review and hypothesis}

2.1 Virtual brand community

A community is a social organisation of people who share knowledge, values and goals (Jonassen et al., 1998). Group members come to depend upon each other to accomplish certain goals. Groups become communities when the interaction and togetherness between group members last long enough to form a set of habits and conventions (Wilson and Ryder, 1996). With the rise of today's new media, the concept of traditional communities has been challenged by online communities. Communities no longer exist only in the physical world but also in the virtual world that operates through the internet (Lee and Lee, 2010).

A virtual community has been described as a group of people who interact online with others in a sustained and repetitive manner who are not bound by physical geography (Ridings and Gefen, 2004), as any group of people who communicate shared interests electronically (Dennis et al., 1998), and those engaged in an intentional social action derived from distinct common interests (Bagozzi and Dholakia, 2002), among other conceptualizations. A virtual community provides opportunities to bring a variety of people together from different backgrounds and allows them to find common ground in their beliefs and interests. Individuals in online communities not only provide knowledge and information resources to the group related to certain agreed upon topics of mutual interests, but also interact with group members (Madritch and Hunter, 2002).

Kolter (1991) defines a brand as "a name, term, sign, symbol, or design, or combination of them which is intended to identify the goods and services of one seller or group of sellers and to differentiate them from those of competitors". Brand community was proposed by Muñiz and O'Guinn (2001), as a "specialized, non-geographically bound community, based on a structured set of social relations among admirers of a brand". Brand communities are explicitly commercial social groups centred on a brand, rather than incidental contact with commercial space. According to the above literatures, Facebook pages are a kind of virtual brand communities, as the members of Facebook pages can access the communities anywhere and to gather together virtually to discuss and share the ideas of the brand. In the next sections we examine the various factors affecting user's experience of Facebook pages.

\subsection{Factors}

2.2.1 Perceived ease of use and perceived usefulness. In considering how to operate a good web site as a virtual community to provide users with good experiences when they connect to the Facebook pages, we first proposed to adopt a concept from Technology Acceptance Model (TAM) (Davis, 1989). The TAM has received considerable support over the years. It has been validated over a wide range of systems, and perceived usefulness and perceived ease of use have proven to be reliable and valid cognitive dimensions (Ahn et al., 2007; Hsu and Lin, 2008; Lu et al., 2008). 
According to the TAM, we can see that perceived ease of use and perceived usefulness influence the user's behaviour to use new IS by influencing intention.

To understand the factors driving people to use new technical media, we also considered uses and gratifications paradigm (UGP) (Blumler and Katz, 1974), originally developed and employed by communication researchers to understand people's motivations for using different media (Flanagin and Metzger, 2001; McQuail, 1987), social psychological model of goal-directed behaviour (Perigini and Bagozzi, 2001) and social identity theory (Taifel, 1978) as underlying frameworks to present various factors as in several studies, they have been used to understand the benefits that virtual communities can provide their current and potential members, and thus attract more people to participate as members (Dholakia et al., 2003). We discovered these theories to be very similar to the TAM. All these theories are often used to explain that people use new media often in a goal-directed way to fulfil some needs (Ahn et al., 2007; Hsu and Lin, 2008; Lu et al., 2008; Ko et al., 2005; Stafford et al., 2004). Dholakia et al. (2003) develops a model based on the UGP which included the five values that people would derive while they join communities: "purposive" value, "self-discovery" value, value of "maintaining interpersonal interconnectivity", "social enhancement" value and "entertainment" value, to explain users' individual motivations in using virtual communities.

Purposive value is constructed from a marketing perspective. It is defined as "the value derived from accomplishing some pre-determined instrumental purpose" (including giving or receiving information). The second value, "self-discovery", involves understanding and deepening salient aspects of one's self through social interactions. One aspect of self-discovery is to interact with others in order to access social resources and facilitate the attainment of one's future goals (McKenna and Bargh, 1999). Another aspect of self-discovery is that such interactions may help one to form, clearly define and elaborate one's own preferences, tastes and values. The third value is maintaining interpersonal connectivity and the fourth value is social enhancement. They have been considered to be contained within group referent which is defined as a kind of social benefit. The last value is entertainment value, derived from fun and relaxation through playing or otherwise interacting with others. Studies have shown that many participants do so for entertainment through exploring different fictional identities, encountering, and solving virtual challenges, etc. (McKenna and Bargh, 1999).

To discuss purposive value derived from joining Facebook pages the virtual community of new social internet web site should be treated as a new tech-media. We discovered that many studies have discussed related topics while TAM models included perceived usefulness. Carpenter et al. (2005) indicated that the utilitarian values derived from an economic concept in the information-processing paradigm are the result of useful, economically efficient and productive experiences, while hedonic values are the outcome of fun, pleasure and enjoyable experience. Thus, we can see that the Purposive value has been proven to be a factor affecting user adoption of a new technical media, such as Facebook pages. Thus, based on the discussion here, we combine the TAM model and the brand experience from the marketing point of view and propose the following hypotheses:

H1. Perceived ease of use influences Facebook pages' brand experience positively.

H2. Perceived usefulness influences Facebook pages' brand experience positively.

H3. Perceived ease of use influences Facebook pages' perceived usefulness.
Commercial value of social networks

579 
JEIM

27,5

580
2.2.2 Brand love. Carroll and Ahuvia (2006) defined love for a brand as "the degree of passionate emotional attachment that a person has for a particular trade name". and conceptualised it as a type of satisfaction. According to their study, brand love differs from the satisfaction construct in several key views. The differences between brand love and satisfaction concept are: while satisfaction generally is conceptualised as a cognitive judgement, brand love has a much stronger affective focus on brands; brand love is often the result of a consumer's long-term relationship with the brand as satisfaction typically is considered as a transaction-specific outcome; while satisfaction frequently is linked to the expectancy disconfirmation paradigm, brand love requires neither expectancy nor disconfirmation, and brand love includes a willingness to declare love such as consumers would say: "I love this brand!" and involves integration of the brand into the consumer's identity, neither of which is requisite in regard to satisfaction. In this case, we assume that it does not matter how useful or ease of use the system is, if you love the brand, you will continue to support or use their Facebook pages. From Albert et al. (2007), consumers' love includes the following characteristics: passion for a brand, brand attachment, positive evaluation of the brand, positive emotions in response to the brand, and declarations of love towards the brand. Therefore, by combining the characteristics of brand love and TAM, we study how consumers like to access the Facebook pages hosted by the brand they love to explore information and interact with the brand. Hence, we propose the following hypotheses:

H4. Brand love influences Facebook pages' perceived ease of use positively.

H5. Brand love influences Facebook pages' perceived usefulness positively.

2.2.3 Brand experience. Consumer and marketing research has shown that experience occurs when consumers search for and purchase products or services (Arnould et al., 2002; Brakus et al., 2008). However, experience can also occur indirectly, such as: when consumers are exposed to advertising and marketing communications from both physical or virtual channels and platforms (Brakus et al., 2009). Brand experience comprises all of the brand-related stimuli, such as: brand-identifying colours (Bellizzi and Hite, 1992; Gorn et al., 1997; Meyers-Levy and Peracchio, 1995), shapes (Veryzer and Hutchinson, 1998), typefaces, background design elements, slogans, mascots and brand characters (Keller, 1987). Brand experience is related but also conceptually distinct from other brand constructs. According to the study provided by Brakus et al. (2009), brand experiences comprise characteristics such as brand experiences include: specific sensations, feelings, cognitions, and behavioral responses triggered by specific brand-related stimuli; experiences can happen when consumers do not show interest in or have a personal connection with the brand; brands which consumers are highly involved with are not necessarily brands that evoke the strongest experiences; brand experiences do not occur only after consumption, they occur whenever there is a direct or indirect interaction with the brand; and a brand experience does not need to be surprising; it can be either expected or unexpected. A long-lasting brand experience stored in consumers' memory would affect consumer satisfaction and loyalty (Oliver, 1997; Reicheld, 1996). In our study, where we are interested in the brand experience over the internet we define brand experience as a user sensory, affective, behaviour, and intellectual response to the brand's Facebook page. According to the characteristics of brand experience, Facebook pages, as a kind of virtual brand community, could 
enhance consumers' brand experiences when consumers interact with brands via Facebook pages personally or as a community. We thus assume that if consumers love the brand, even they encounter less positive brand experience over the internet, they will still loyal to the brand or continue to support the brand. Hence, we propose the following hypothesis:

H6. Brand love influences Facebook pages' brand experience positively.

A new concept concerning the effort required of customers is proposed by Dixon et al. (2010). They argue that the most important thing for businesses is to help consumers solve their problems using the services or products which those companies provide. They also suggest that convenience is vital in ensuring customer loyalty. In their study, they discover that rather than rewarding companies which provide a positive experience, consumers are more likely to punish companies for bad service. Their research suggests that reducing the amount of effort required of consumers is vitally important. Following on from this, we also think that taking interactions with customers might reduce the likelihood that users would visit brand Facebook pages and therefore have defined customer efforts in this study as the effort required to interact with a brand through their Facebook page. For example, companies hosting promotional activities on Facebook may require participants to provide detailed information, or to make a great effort to engage in activities, or cause users to feel uneasy about making contact with the brand in search of basic information. This kind of effort may lead consumers to reduce their Facebook page usage due to a less than positive brand experience, perceived ease of use and perceived usefulness. Therefore, we propose the following hypotheses:

H7. Consumer effort influences Facebook pages' perceived ease of use positively.

H8. Consumer efforts influences Facebook pages'perceived usefulness positively.

H9. Consumer effort influences Facebook pages'brand experience positively.

Next, we will analyse loyalty and e-word of mouth as outcomes of the company-user relationship.

\subsection{Outcomes}

2.3.1 Loyalty to brand Facebook pages. According to Anderson and Srinivasan's (2003) study, e-loyalty is defined as a customer's favourable attitude towards an online business, resulting in repeated buying and engagement with that company. Schultz (2000) sees consumer loyalty or brand loyalty in cyberspace as an evolution of the traditionally product-driven, marketing-stimulated business model, moving towards a distribution-driven, consumer-controlled and technology-facilitated model. Additionally, Corstjens and Lal (2000) point out that e-loyalty is comparable to the familiar concept of "store loyalty", building repeated store visits into consumer behaviour and encouraging the sale of established brand name items in the store. Also, refer to the above definition of loyalty defined with regard to Facebook pages as loyalty evaluated according to the degree of loyalty evident in users towards business Facebook pages. From the above studies we can see that the concept of e-loyalty extends beyond traditional concepts of brand loyalty to online consumer behaviour. Jevons and Gabbott (2000) present several
Commercial value of social networks

581 
JEIM

27,5

582 structural models of trust in the field of e-loyalty and its relationship to repeated visits to e-commerce sites. Oliver (1997) and Reicheld (1996) posit that a long-lasting brand experience, stored in a consumers' memory, will affect consumer satisfaction and loyalty. Therefore, we propose that brand experience will affect loyalty to Facebook pages through its reinforcement of consumers' satisfaction and loyalty. Therefore, hypothesis is as follows:

H10. Brand experience influences loyalty to brand Facebook pages positively.

2.3.2 E-WOM. Word-of-mouth is commonly defined as informal communication relating to the characteristics of a business or product occurring between consumers (Westbrook, 1987). Word-of-mouth also refers to information communication between private parties regarding the evaluation of goods and services (Dichter, 1966; Singh, 1988). Word-of-mouth may have a positive, neutral or negative impact upon the company or product discussed. Most importantly, word-of-mouth as a phenomenon enables consumers to exert both informational and normative influence upon the product evaluation and purchasing behaviour of fellow consumers (Bone, 1995; Ward and Reingen, 1990). Many studies propose that loyal, satisfied customers will engage in word-of-mouth behaviour favourable to the firm (Bitner, 1990; Hunt, 1977; Reichheld and Sasser, 1990). Consistent with this perspective, Swan and Oliver (1989) found a positive relationship between customer satisfaction and word-of-mouth. Additionally, Hennig-Thurau et al. (2004) identify four motives associated with word-of-mouth: concern for others, helping the company, social benefit and exerting power. Among these four motives, helping the company comes as a result of consumer satisfaction with a product and the subsequent desire to help the company by relating their experiences to others (Sundaram et al., 1998). Therefore, we suggest that brands with a high proportion of satisfied consumers would be most likely to obtain positive evaluations from their consumers and thus define word-of-mouth in our study as the willingness of users to provide positive word-of-mouth for a company's Facebook page. Referring to word-of-mouth as defined above, we propose the following hypothesis:

H11. Loyalty to brand Facebook pages influences word-of-mouth positively.

We also observed that Facebook page users are able to click "Like" and post any information they enjoyed or found interesting (positive experience) to their own pages in order to share it with their Facebook friends. Therefore, we also propose the following hypothesis:

H12. Facebook pages' brand experience influences word-of-mouth positively.

As mentioned previously, customers enjoy positive brand experience when perceived ease of use and perceived usefulness are also positive. As a result, we infer that positive perceived ease of use and perceived usefulness would influence word-of-mouth positively. Accordingly, we propose the following further hypotheses:

H13. Facebook pages' perceived usefulness influences word-of-mouth positively.

H14. Facebook pages' perceived ease of use influences word-of-mouth positively. 
Based on the above analysis, we have proposed a model, illustrated in Figure 1. We will discuss how Facebook pages improve E-WOM with relation to specific brands and the ways in which consumers are attracted to join and continue to make use of a company's (brand's) Facebook pages by providing a positive brand experience. The model focuses on the effectiveness of Facebook pages with regard to E-WOM, brand experience and customer loyalty to brand Facebook pages. It also takes into consideration the new concept of consumer effort in order to approximate its impact upon E-WOM.

\section{Methodology}

We adopted an online survey method for data collection. The subjects we used for the study were Facebook users who have joined Facebook pages. The data were collected in Taiwan over spring 2011. Facebook has been extremely successful in Taiwan according to Facebook.com's traffic rankings (www.alexa.com/siteinfo/facebook.com). Subjects were chosen using a convenience sampling method, which developed into snowball sampling (Goodman, 1961) as more Facebook users recommended other users who were willing to participate in the survey. Convenience sampling generally assumes a homogeneous population and that one person is similar to another. In the case of our research this would be with reference to the user's online habits. While individuals are of course different from one another, the difference is seen to be probabilistic (Berk and Freedman, 1995; Cochran, 1977; Diamond, 2000), with users sharing habits more commonly than they differ in them.

In order to validate the proposed model, we used the structural equation model (SEM) to analyse the data collected. The measured items were developed based on a seven-point "Liker" scale (raging from $1=$ "not at all descriptive" to $7=$ "extremely descriptive"). The questionnaire was distributed by e-mail, Facebook and on Facebook pages, with a prize draw offered as an incentive for participation. The study was tested ahead of final distribution. Subjects of this initial test were Facebook users who were willing to participate in a test survey without incentive. At the pre-testing stage, we collected 57 questionnaires from a total of 28 males and 29 females. In doing so, we adopted Cronbach's $\alpha$ in order to estimate the reliability of measures for each variable in our study.

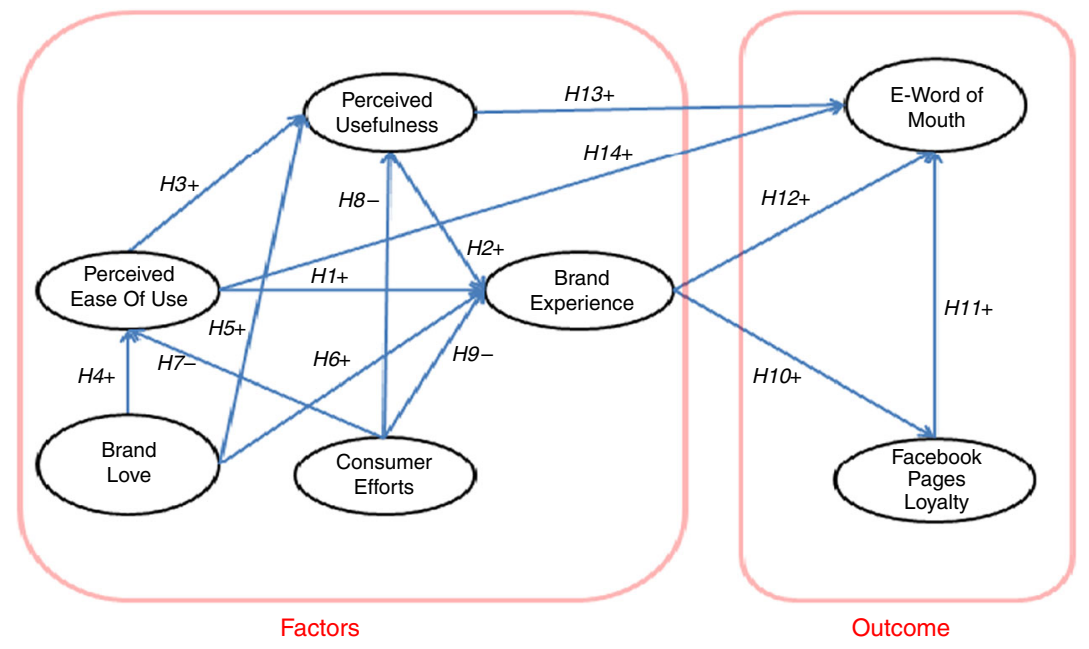

Figure 1. Research model 
JEIM

27,5

584

According to Table I, Cronbach's $\alpha$ for all of the variables come to over 0.7 (DeVellis, 1991), meaning that the measures are consistent. In order to reduce the quantity of questionnaires required and improve the survey's performance and quality, we referred to the "scale if the item deleted" while we processed the Cronbach's $\alpha$ testing to cancel out measures with lower reliability, and modify the wording of some measures according to feedback from participants in producing the final questionnaire. The survey was introduced to participants as an "opinion survey regarding brand image and word-of-mouth on Facebook pages". Participants were asked to indicate the Facebook pages they most often visited when connected to Facebook. After dropping the invalid samples, a total of 532 participants had completed the survey. The respondents profile is shown in Table II.

This study uses Cronbach's $\alpha$ and confirmatory factor analysis (CFA) to measure the questionnaire's reliability and validity according to each construct. Table III shows the reliability results for the final version of our questionnaire. According to Table III, the Cronbach's $\alpha$ for each of the constructs listed comes out above 0.7 , from 0.904 to 0.960 , indicating excellent reliability. Construct reliability (CR) for each

\begin{tabular}{lcc}
\hline Variable name & Measure items & Cronbach's $\alpha$ \\
\hline & & \\
Brand love & 8 & 0.937 \\
Perceived ease of use & 4 & 0.916 \\
Perceived usefulness & 5 & 0.834 \\
Brand experience & 12 & 0.934 \\
Facebook pages loyalty & 4 & 0.924 \\
E-word-of-mouth & 3 & 0.880 \\
Customer effort & 4 & 0.947 \\
\hline
\end{tabular}

Table I.

Cronbach's $\alpha$ for each variable

\begin{tabular}{lcc}
\hline & Subjects & Percentage \\
\hline Gender & & \\
Male & 210 & 39.5 \\
Female & 322 & 60.5 \\
Total & 532 & \\
Age & & \\
Over 40 years old & 42 & 7.9 \\
36-40 years old & 48 & 9.0 \\
$31-35$ years old & 111 & 20.9 \\
26-30 years old & 151 & 28.4 \\
$21-25$ years old & 130 & 24.4 \\
16-20 years old & 48 & 9.0 \\
$<15$ years old & 2 & 0.4 \\
Facebook usage years & & \\
< months & 18 & 3.4 \\
3-6 months & 30 & 5.6 \\
months-1 year & 96 & 48.0 \\
1-2 years & 231 & 18.8 \\
$2-3$ years & 100 & 4.9 \\
3-4 years & 26 & 5.8 \\
Over 4 years & 31 &
\end{tabular}


construct is $>0.5$ and the average variance extracted (AVE) for most of constructs is $>0.5$, above the standard suggested by Bagozzi and Yi (1988). The AVE index was also used to estimate convergent validity. As already noted, the AVE for most constructs is $>0.5$ and therefore the constructs proposed may be measured effectively. We adopted the CFA to measure the validity of each construct. Table IV shows the evaluative results of our CFA. As seen in Table IV, the goodness of fit with regard to construct models has been assessed using $\chi^{2}$-tests, root mean square error of approximation (RMSEA), non-normed fit index (NNFI) and the comparative fit index (CFI). Discussions of these indices can be found in Bentler (1990), Browne and Cudeck (1993), Marsh and Hovecar (1985), and Marsh et al. (1996). The indices of the constructs in our study all met the required standard, as NFI, NNFI, CFI, IFI, RFI, GFI, and AGFI were all $>0.90$, meaning that the goodness of fit for each construct is excellent, with SRMR close to 0 and RMSEA $<0.50$.

Discriminant validity is supported when the AVE of each construct is greater than the shared variance between each pair of constructs. In other words, the squared correlation between constructs. This criterion is met for all possible construct pairs. Ultimately, the measurement model is supported, as is shown in Table V.

This study uses SEM to process path analysis and to estimate if each hypothesis, as well as the relationships inside the model, is valid. We estimate a SEM using the AMOS to assess path coefficients and test the relationships proposed in our conceptual model. The structural model shows a good fit to the data as shown in Table VI for the evaluation of model fitting and Table VII for the recommended values of model fit measures.

\begin{tabular}{|c|c|c|c|c|c|}
\hline Constructs & Measure items & Cronbach's $\alpha$ & $\mathrm{CR}$ & AVE & \\
\hline Brand love & 5 & 0.942 & 0.943 & 0.768 & \\
\hline Perceived ease of use & 3 & 0.950 & 0.951 & 0.865 & \\
\hline Perceived usefulness & 4 & 0.930 & 0.931 & 0.770 & \\
\hline Brand experience & 12 & 0.964 & 0.931 & 0.772 & \\
\hline Facebook pages loyalty & 3 & 0.904 & 0.913 & 0.780 & Table III. \\
\hline E-word of mouth & 3 & 0.921 & 0.923 & 0.800 & Reliability for each \\
\hline Customer effort & 4 & 0.960 & 0.961 & 0.861 & construct \\
\hline
\end{tabular}

\begin{tabular}{|c|c|c|c|c|c|c|c|c|}
\hline Items & $\begin{array}{l}\text { Brand } \\
\text { love }\end{array}$ & $\begin{array}{c}\text { Perceived ease } \\
\text { of use }\end{array}$ & $\begin{array}{l}\text { Perceived } \\
\text { usefulness }\end{array}$ & $\begin{array}{c}\text { Brand } \\
\text { experience }\end{array}$ & $\begin{array}{c}\text { Facebook pages } \\
\text { loyalty }\end{array}$ & $\begin{array}{c}\text { E- } \\
\text { WOM }\end{array}$ & $\begin{array}{l}\text { Customer } \\
\text { effort }\end{array}$ & \\
\hline NFI & 0.980 & 1.000 & 0.988 & 0.993 & 0.998 & 1.000 & 0.989 & \\
\hline NNFI & 0.964 & 1.002 & 0.968 & 0.983 & 0.996 & - & 0.967 & \\
\hline CFI & 0.982 & 1.000 & 0.989 & 0.994 & 0.999 & 1.000 & 0.990 & \\
\hline IFI & 0.982 & 1.001 & 0.989 & 0.994 & 0.999 & 1.000 & 0.990 & \\
\hline RFI & 0.960 & 1.000 & 0.965 & 0.979 & 0.993 & - & 0.967 & \\
\hline SRMR & 0.0178 & 0.004 & 0.0146 & 0.0109 & 0.0084 & 0.000 & 0.0111 & \\
\hline RMSEA & 0.129 & 0.000 & 0.131 & 0.099 & 0.054 & - & 0.155 & \\
\hline GFI & 0.963 & 1.000 & 0.980 & 0.989 & 0.997 & 1.000 & 0.975 & \\
\hline AGFI & 0.889 & 1.000 & 0.902 & 0.944 & 0.981 & - & 0.786 & Table IV. \\
\hline$\chi^{2}$ & 48.988 & 0.053 & 20.272 & 12.410 & 2.575 & 0.000 & 27.638 & Results of CFA \\
\hline $\mathrm{df}$ & 5 & 1 & 2 & 2 & 1 & 0 & 2 & evaluation for each \\
\hline$\chi^{2} / \mathrm{df}$ & 9.798 & 0.053 & 10.136 & 6.205 & 2.575 & - & 13.819 & construct \\
\hline
\end{tabular}

Commercial value of social networks

585 
JEIM

27,5

586

Furthermore, to evaluate the predictive validity and value for our proposed model, we collected additional 431 samples to assess how well the proposed model performs on the hold-out data. The evaluation is shown in Table VI. According to the test results, it shows the model fit from the hold-out samples echo our original proposed results.

In addition, considering the various "customer effort" is a new concept, to support the hypotheses we proposed, we also carried out an Alternative Path Test in our study. In the proposed model, we consider that the model will be influenced by "customer effort" through "perceived usefulness", "perceived ease of use" and "brand experience".

\begin{tabular}{lccccccccc}
\hline Items & $M$ & $\mathrm{SD}$ & $\mathrm{BL}$ & $\mathrm{PE}$ & $\mathrm{PU}$ & $\mathrm{BE}$ & \multicolumn{1}{c}{$\mathrm{FL}$} & $\mathrm{EW}$ & $\mathrm{CE}$ \\
\hline $\mathrm{BL}$ & 5.537 & 1.100 & 0.768 & 0.245 & 0.340 & 0.411 & 0.228 & 0.285 & 0.005 \\
$\mathrm{PE}$ & 5.768 & 1.007 & 0.495 & 0.865 & 0.590 & 0.386 & 0.312 & 0.381 & 0.001 \\
$\mathrm{PU}$ & 5.699 & 0.997 & 0.583 & 0.768 & 0.770 & 0.471 & 0.362 & 0.432 & 0.012 \\
$\mathrm{BE}$ & 5.371 & 0.978 & 0.641 & 0.621 & 0.686 & 0.772 & 0.582 & 0.640 & 0.077 \\
$\mathrm{FL}$ & 5.056 & 1.247 & 0.478 & 0.559 & 0.602 & 0.763 & 0.780 & 0.637 & 0.097 \\
$\mathrm{EW}$ & 5.397 & 1.099 & 0.534 & 0.617 & 0.657 & 0.800 & 0.798 & 0.800 & 0.043 \\
$\mathrm{CE}$ & 3.894 & 1.515 & -0.072 & -0.027 & -0.110 & -0.278 & -0.312 & -0.207 & 0.861
\end{tabular}

Table V.

Squared pair wise correlation between latent constructs
Notes: BL, brand love; PE, perceived ease of use; PU, perceived usefulness; BE, brand experience; FL, Facebook pages loyalty; EW, E-word of mouth; CE, customer effort
Table VI.

The evaluation of model fitting and results of hypothesis test of hold-out sample

\begin{tabular}{lcc}
\hline Name & Model & Hold-out sample model \\
\hline NFI & & \\
NNFI & 0.938 & 0.932 \\
CFI & 0.948 & 0.947 \\
IFI & 0.955 & 0.953 \\
RFI & 0.955 & 0.954 \\
SRMR & 0.928 & 0.922 \\
RMSEA & 0.0456 & 0.0445 \\
GFI & 0.067 & 0.069 \\
AGFI & 0.83 & 0.862 \\
$\chi^{2}$ & 0.842 & 0.829 \\
df & 955.278 & 856.602 \\
$\chi^{2} /$ df & 283 & 283 \\
\end{tabular}

Measurement Stand Our study Literature

\begin{tabular}{|c|c|c|c|c|}
\hline & Measurement & Stand & Our study & Literature \\
\hline \multirow[t]{4}{*}{ Absolute fit measures } & $\chi^{2} / \mathrm{df}$ & $<5$ & 3.376 & Marsh and Hovecar (1985) \\
\hline & GFI & $>0.8$ & 0.873 & Etezadi Amoli and Farhoomand (1996) \\
\hline & RMSEA & $<0.08$ & 0.067 & Belanger and Carter (2008) \\
\hline & SRMR & $<0.08$ & 0.0456 & $\mathrm{Hu}$ and Bentler (1999) \\
\hline \multirow[t]{4}{*}{ Incremental fit measure } & IFI & $>0.9$ & 0.955 & Hu and Bentler (1999) \\
\hline & NFI & $>0.9$ & 0.938 & Hu and Bentler (1999) \\
\hline & NNFI & $>0.9$ & 0.948 & Hu and Bentler (1999) \\
\hline & CFI & $>0.9$ & 0.955 & Bentler (1990) \\
\hline \multirow[t]{2}{*}{ Parsimonious fit measures } & PGFI & $>0.5$ & 0.704 & Mulaik (1989) \\
\hline & PNFI & $>0.5$ & 0.816 & Mulaik (1989) \\
\hline
\end{tabular}

Table VII.

The recommended values of model fit measures 
However, to evaluate the effect by "customer effort" towards the model, we carried out an Alternative Path Test to our original model by terminating the H12 and H13 (see alternative model 1 - in Table VIII). To enhance the predictive validity, we also carried out another Alternative Path Test by terminating H14 (see alternative model 2 - in Table VIII). According to the test results, we discovered that although Alternative Test Model 1 and Alternative Test Model 2 are both fit, each measure of model fit for our original model is still better than the two models we produced for Alternative Path Test. We thus can conclude that the original model is most fit for our study which demonstrates the benefit of introducing the concept of customer effort in our model.

\section{Research findings}

\subsection{Path results for the proposed model}

We have estimated specific construct and model relationships from the data for the proposed model. The results are shown in Figure 2.

\begin{tabular}{|c|c|c|c|c|}
\hline Measurement & Original Model & Alternative Model 1 & Alternative Model 2 & \\
\hline NFI & 0.938 & 0.937 & 0.934 & \\
\hline NNFI & 0.948 & 0.948 & 0.944 & \\
\hline CFI & 0.955 & 0.955 & 0.951 & \\
\hline IFI & 0.955 & 0.955 & 0.952 & \\
\hline RFI & 0.928 & 0.928 & 0.924 & \\
\hline SRMR & 0.0456 & 0.470 & 0.0716 & \\
\hline RMSEA & 0.067 & 0.067 & 0.069 & \\
\hline GFI & 0.83 & 0.872 & 0.862 & \\
\hline AGFI & 0.842 & 0.842 & 0.829 & \\
\hline$\chi^{2}$ & 955.278 & 961.410 & $1,011.540$ & \\
\hline $\mathrm{df}$ & 283 & 285 & 284 & Table VIII. \\
\hline$\chi^{2} / \mathrm{df}$ & 3.376 & 3.373 & 3.562 & Alternative path test \\
\hline
\end{tabular}

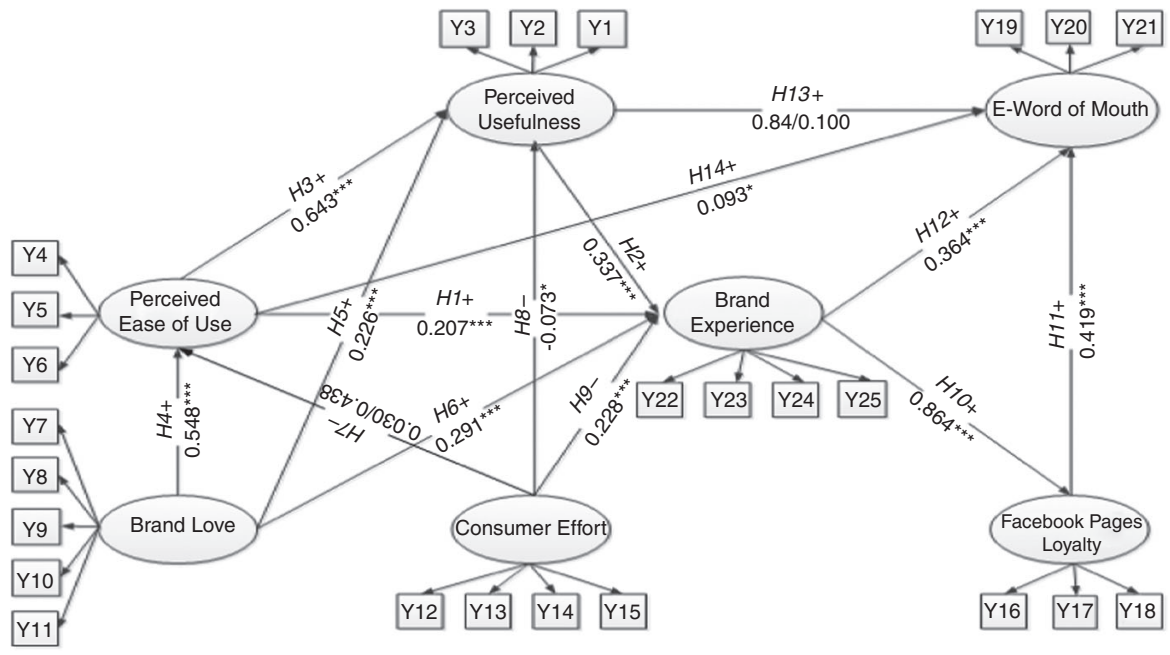

Notes: ${ }^{*} p$-value $<0.05 ;{ }^{* *} p$-value $<0.01 ;{ }^{* * *} p$-value $<0.001$

Figure 2. The estimated parameters for model 
JEIM

27,5

588
The results show that perceived usefulness influenced brand experience (H1: $\mathrm{SE}=0.337 ; t$-value $=6.107)$, perceived ease of use influenced brand experience $(H 2$ : $\mathrm{SE}=0.207 ; t$-value $=4.038$ ) and perceived ease of use influenced perceived usefulness $(H 3: \mathrm{SE}=0.643, t$-value $=15.759)$. The results echo the TAM model as both perceived usefulness and perceived ease of use are positively influenced by brand experience, and perceived ease of use influenced perceived usefulness. According to the above results, the high degree of perceived ease of use indicates that users of Facebook pages perceive Facebook pages as useful only when they can easily achieve their goal by utilising the Facebook page. Facebook page users enjoy positive brand experience when they feel that the Facebook pages they access are useful and easy to use. Hence, our $H 1, H 2$, and $H 3$ are supported.

Considering whether brand love influences user perception of Facebook pages, we found that brand love influenced perceived ease of use (H4: $\mathrm{SE}=0.545$, $t$-value $=13.227)$ and perceived usefulness $(H 5: \mathrm{SE}=0.226, t$-value $=5.945)$, as users would keep using Facebook pages so long as they remained attached to the brand and wished to continue interacting with it. Due to their passion for the brand, users perceived their Facebook page as useful and easy to use. Thus, $H 4$ and $H 5$ are supported. In considering the influence of brand love and brand experience (H6: $\mathrm{SE}=0.291$; $\mathrm{t}$-value $=7.225$ ), consumers obtain positive brand experience when they perceive that Facebook pages are worth using. Therefore, $H 6$ is supported.

Given brand experience influenced $\mathrm{E}-\mathrm{WOM}(\mathrm{H12}: \mathrm{SE}=0.364, t$-value $=6.871)$, loyalty to $\mathrm{E}-\mathrm{WOM}(H 11$ : $\mathrm{SE}=0.419, t$-value $=8.754)$ and loyalty to brand Facebook pages $(H 10$ : $\mathrm{SE}=0.864, t$-value $=16.935)$, we found that positive brand experience drove users to distribute positive E-WOM and continue using Facebook pages, thereby enhancing loyalty to brand Facebook pages. In addition, while these Facebook page users keep using brand Facebook pages, they also distributed positive E-WOM for the brand by clicking "Like". Therefore, our proposed H1O, H11, and H12 are supported.

Considering the paths perceived usefulness to E-WOM (H13: $\mathrm{SE}=0.084$; $t$-value $=1.645$ ) and perceived ease of use to E-WOM (H14: $\mathrm{SE}=0.093$; $t$-value $=2.025$ ), our results show that customers would like to disseminate E-WOM for brand Facebook pages if they think the content or information provided is easy to use. However, they would not like to distribute E-WOM if they only think that the brand Facebook page is useful. Thus, H14 is supported, but H13 is not.

Finally, in considering the influence of customer effort upon brand experience (H9: $\mathrm{SE}=-0.228, t$-value $=-7.558)$, perceived usefulness (H8: $\mathrm{SE}=-0.073$, $t$-value $=-2.834)$ and perceived ease of use $(H 7: \mathrm{SE}=0.030, t$-value $=0.775)$, we found that while the influence of customer effort upon brand experience and on perceived usefulness are clear, customer effort on perceived ease of use is not. This is probably due to the ease of use functions and interfaces of Facebook pages provided to consumers to operate and interact with the brand and other fans, such as by clicking "Like" and posting short messages similar in style to a mobile phone text message. Therefore, with regard to the interfacing and operating methods of Facebook pages, customer effort cannot be perceived clearly, so the influence of customer effort towards perceived ease of use remains unclear. Hence, $H 8$ and $H 9$ are supported, but $H 7$ is not. Table IX shows the SEM results which support our proposed hypotheses. Again, to evaluate the predictive validity and value for our proposed model, we ran a test on the estimate value for each hypothesis we proposed from the hold-out sample. The result shows the estimate value for each hypothesis we proposed echo our original 


\begin{tabular}{|c|c|c|c|c|c|}
\hline & S.E. & $t$ Value & $p$-value & Label & Commercic \\
\hline$H 1: \mathrm{BE} \leftarrow \mathrm{PE}$ & 0.207 & 4.038 & $* * *$ & Support & networks \\
\hline$H 2: \mathrm{BE} \leftarrow \mathrm{PU}$ & 0.337 & 6.107 & $* * *$ & Support & \\
\hline H3: $\mathrm{PU} \leftarrow \mathrm{PE}$ & 0.643 & 15.759 & $* * *$ & Support & \\
\hline$H 4: \mathrm{PE} \leftarrow \mathrm{BL}$ & 0.545 & 13.227 & $* * *$ & Support & \\
\hline$H 5: \mathrm{PU} \leftarrow \mathrm{BL}$ & 0.226 & 5.945 & $* * *$ & Support & 589 \\
\hline$H 6: \mathrm{BE} \leftarrow \mathrm{BL}$ & 0.291 & 7.225 & $* * *$ & Support & \\
\hline$H 7: \mathrm{PE} \leftarrow \mathrm{CE}$ & 0.030 & 0.775 & 0.438 & Not support & \\
\hline$H 8: \mathrm{PU} \leftarrow \mathrm{CE}$ & -0.073 & -2.834 & $*$ & Support & \\
\hline H9: $\mathrm{BE} \leftarrow \mathrm{CE}$ & -0.228 & -7.558 & $* * *$ & Support & \\
\hline H1O: FL $\leftarrow \mathrm{BE}$ & 0.864 & 16.935 & $* * *$ & Support & \\
\hline H11: EW $\leftarrow \mathrm{FL}$ & 0.419 & 8.754 & $* * *$ & Support & \\
\hline H12: $\mathrm{EW} \leftarrow \mathrm{BE}$ & 0.364 & 6.871 & $* * *$ & Support & \\
\hline H13: EWPU & 0.084 & 1.645 & 0.100 & Not Support & \\
\hline H14: $\mathrm{EW} \leftarrow \mathrm{PE}$ & 0.093 & 2.025 & $*$ & Support & \\
\hline
\end{tabular}

Notes: BL, brand love; PE, perceived ease of use; PU, perceived usefulness; BE, brand experience; FL, Facebook pages loyalty; EW, E-word of mouth; CE, customer effort

Table IX. Results of hypothesis test

proposed results. Thus, the hold-out sample testing provides stronger evidence that our proposed model is valid. Table $\mathrm{X}$ shows the hypothesis test results of hold-out sample.

\section{Discussion and implications}

Our empirical study supports the proposed model. Model test results established the relationships between intrinsic and extrinsic motivations and brand experience, brand Facebook page loyalty and E-WOM. These findings make important contributions in the following areas.

\subsection{A more complete understanding of brand experience}

This study proposed a model to discuss the relationship between brand experience and Facebook, a topic which had been the subject of surprisingly little study up to now.

\begin{tabular}{lcrll}
\hline & SE & $t$-value & $p$-value & Label \\
\hline$H 1: \mathrm{BE} \leftarrow \mathrm{PE}$ & 0.129 & 3.574 & $* * *$ & \\
$H 2: \mathrm{BE} \leftarrow \mathrm{PU}$ & 0.268 & 5.856 & $* * *$ & Support \\
$H 3: \mathrm{PU} \leftarrow \mathrm{PE}$ & 0.610 & 13.992 & $* * *$ & Support \\
$H 4: \mathrm{PE} \leftarrow \mathrm{BL}$ & 0.476 & 12.459 & $* * *$ & Support \\
$H 5: \mathrm{PU} \leftarrow \mathrm{BL}$ & 0.238 & 5.144 & $* * *$ & Support \\
$H 6: \mathrm{BE} \leftarrow \mathrm{BL}$ & 0.245 & 5.977 & $* * *$ & Support \\
$H 7: \mathrm{PE} \leftarrow \mathrm{CE}$ & -0.005 & 1.449 & 0.147 & Not support \\
$H 8: \mathrm{PU} \leftarrow \mathrm{CE}$ & -0.043 & -2.360 & $* *$ & Support \\
$H 9: \mathrm{BE} \leftarrow \mathrm{CE}$ & -0.035 & -5.934 & $* * *$ & Support \\
$H 10: \mathrm{FL} \leftarrow \mathrm{BE}$ & 0.864 & 16.255 & $* * *$ & Support \\
$H 11: \mathrm{EW} \leftarrow \mathrm{FL}$ & 0.419 & 7.517 & $* * *$ & Support \\
$H 12: \mathrm{EW} \leftarrow \mathrm{BE}$ & 0.364 & 5.004 & $* * *$ & Support \\
$H 13: \mathrm{EW} \leftarrow \mathrm{PU}$ & 0.084 & 1.835 & 0.066 & Not support \\
$H 14: \mathrm{EW} \leftarrow \mathrm{PE}$ & 0.093 & 2.514 & $*$ & Support \\
Notes: $* p<0.05 ; * * p<0.01 ; * * * p<0.001 ;$ & & & \\
\hline
\end{tabular}


JEIM

27,5

590
The model yielded detailed variance in brand experience with regard to consumer motivations. The emerging view of brand experience is recognised as the confluence of evaluation and relational factors (Brakus et al., 2009). This system of determinants has not been conceptually integrated or empirically tested before. As proposed in the model, intrinsic motivations like brand love and extrinsic motivations such as perceived ease of use, perceived usefulness and customer effort, influence brand experience and consequently influence brand Facebook loyalty and E-WOM. With regard to what our study suggests that positive brand experience makes customers loyal and likely to employ word-of-mouth on behalf of the brand. This is something that is well established in traditional marketing literature but has not been confirmed in the case of new media such as social networks, which was the context of this study.

\subsection{Establishment of customer effort as a new variable and the development of its determinants}

As suggested by Barwise and Meehan (2010), in past studies, scholars discussing topics related to online marketing focused out how to attract customers towards making use of the system. Few studies discussed the excessive offerings of those systems, which can impact negatively upon customer brand experience. Utilising this new variable we found that customer effort negatively impacts upon brand experience in many ways, as customers have to spend a lot of time and take many steps in order to achieve their goal. In addition, from a technological perspective, customer effort also directly influences perceived ease of use and perceived usefulness, in addition to influencing brand experience indirectly.

\subsection{Brand experience}

As mentioned previously, experience is an important topic in the field of contemporary marketing, hoping to provide customers with positive experience by utilising platforms such as Facebook pages. To understand motivations for joining brand Facebook pages and therefore having a positive brand experience, we proposed a model to discuss how a system might influence brand experience. Our study highlighted some interesting results. As with the results from the TAM model, customers tend to have better experiences when they perceive that the system is useful and easy to use. However, if customers love the brand, they will perceive the system as easy to use and useful, while enjoying a better brand experience as well. We can then infer that a brand which is loved by its fans will improve its Facebook page's operating quality. This result echoes the concept posited by Collins (2011) and suggests that companies should not treat their Facebook pages as a panacea for improving brand equity. Companies should operate their brand effectively, ensuring that customers love their brand, and then by extension the technology that supports it. Customers will continue to love the brand and gain positive experience from interacting with it. On the other hand, brand love can also reduce any negative opinions incurred by customers when interacting with a badly designed Facebook page. Our results show that Facebook pages should be treated not very different from company's web sites. As it was clear in the 1990s, when companies first started operating on the internet, that having a web presence is not enough but ease of use and appeal are important we can now confirm that Facebook pages should also receive the same attention in terms of keeping the brand name alive and offer ease of use for users/customers. 
In considering the new concept of consumer effort, our study shows that it has a strong influence not only on the variables perceived usefulness and brand experience, but also on perceived ease of use. This might be due to the interface design of Facebook pages being very easy to use, ensuring that consumers feel events or activities hosted by the brand on Facebook are easy to attend or respond to. However, if the content is not easy to read or conducive to achieving the consumer's goals, perceived usefulness for consumers is reduced, along with their brand experience. This result echoes the idea from Dixon et al. (2010) that consumers care most about the effort required to achieve their goals and fulfil their needs. Hence, based on the results of our study, we suggest that when a brand hosts events or activities on their Facebook page, they should not only consider how fancy the system looks and how rich is the content, but also consider the purpose with which consumers connect to their Facebook pages and become fans, recognising that too much waiting time or too many operation actions pushes customers away, even to the point of ceasing to access the Facebook page altogether. Furthermore, this would provoke negative brand experience from the consumer and thus reduce the possibility of positive word-of-mouth.

\section{Conclusions}

Our study explored the use of Facebook pages as a marketing tool for companies. Primary data rooted in the geographical and cultural context of Taiwan were used and analysed. Consumer attitudes towards brand Facebook pages were examined through a survey based empirical investigation. The findings suggest that users are influenced by the technical characterises of a brand Facebook page, such as ease of use and usefulness, which might be combated by attempting to reduce customer effort when accessing Facebook pages. We conclude that customer effort influenced brand experience and consequently loyalty to brand Facebook pages and E-WOM. The study's contributions are both theoretical and practical, as it offers new insights into brand experience attitudes in an online environment and useful insights to companies willing to market themselves on Facebook.

From a theoretical perspective, the study investigated brand experience and user effort which have not been investigated in the past. Research in these areas in the online community domain has created a new avenue for studying these concepts in a rapidly developing research area.

From a practical point of view, our research provides evidence that the ease of use and usefulness of a Facebook page is of major importance, and apart from taking care of the aesthetics of the page, companies need to avoid overloading users with information and asking them to perform complicated tasks. Additionally, it suggested that the effect of brand experience developed through Facebook pages needs to be taken into consideration when companies are formulating overall marketing strategies.

\section{Limitations and future research}

The limitations of this study relate to the investigation of consumer perspectives in a specific geographical context and time frame. We suggest that future studies investigating Facebook might collect data from various geographical settings and emphasise a variety of cultural perspectives. Additionally, we suggest that future studies might focus on a specific brand/case in order to obtain business data with a business rather than a consumer perspective. This study discusses intrinsic and
Commercial value of social networks

591 
JEIM

27,5

592

extrinsic motivation factors influencing brand experience and its results. However, factors of intrinsic motivation such as brand love, as well as extrinsic motivations such as perceived ease of use, perceived usefulness and customer effort cannot be observed over a short period of time. Given that we adopted a cross-sectional research method in this study to collect data from a time segment, we suggest that future studies adopt a longitudinal research method to support the results of cause and effect.

\section{References}

Adjei, M.T., Noble, S.M. and Noble, C.H. (2009), "The influence of C2C communications in online brand communities on customer purchase behavior", Academy of Marketing Science Journal, Vol. 38 No. 5, pp. 634-653.

Ahn, T., Ryu, S. and Han, I. (2007), "The impact of web quality and playfulness on user acceptance of online retailing", Information \& Management, Vol. 3 No. 7230, pp. 263-275.

Albert, N., Merunka, D. and Valette-Florence, P. (2007), "When consumers love their brands: exploring the concept and its dimensions", Lournal of Business Research, Vol. 61 No. 10, pp. 1062-1075.

Anderson, R.E. and Srinivasan, S.S. (2003), "E-satisfaction and e-loyalty: a contingency framework", Psychology \& Marketing, Vol. 20 No. 2, pp. 123-138.

Arnould, J.E., Price, L.L. and Zinkhan, G.L. (2002), Consumers, 2nd ed., McGraw-Hill/Richard D. Irwin, New York, NY.

Bagozzi, R.P. and Dholakia, U.M. (2002), "Intentional social action in virtual communities", Journal of Interactive Marketing, Vol. 16 No. 2, pp. 2-21.

Bagozzi, R.P. and Yi, Y. (1988), "On the evaluation of structural equation models", Lournal of the Academv of Marketing Science, Vol. 16 No. 1, pp. 74-94.

Barwise, P. and Meehan, S. (2010), "The one thing you must get right when building a brand", Harvard Business Review, Vol. 16 No. 12, pp. 1-5.

Belanger, A. and Carter, L. (2008), “Trust and risk in e-government adoption”, Iournal of Strategic, Vol. 17 No. 2, pp. 165-176.

Bellizzi, J.A. and Hite, R.E. (1992), "Environmental color, consumer feelings, and purchase likelihood", Psychology and Marketing, Vol. 9 No. 5, pp. 347-363.

Bentler, P.M. (1990), "Comparative fit indexes in structural models", Psvchological Bulletin, Vol. 107 No. 2, pp. 238-246.

Berk, R.A. and Freedman, D.A. (1995/2003), "Statistical assumptions as empirical commitments", in Blomberg, T.G. and Cohen, S. (Eds), Law, Punishment, and Social Control: Essays in Honor of Sheldon Messinger, Aldine de Gruyter, NewYork, NY, pp. 245-258.

Bitner, M.J. (1990), "Evaluation service encounters: the effect of physical surroundings and employee responses", Journal of Marketing, Vol. 54 No. 2, pp. 69-82.

Blumler, J.G. and Katz, E. (1974), The Uses of Mass Communications, Sage, Beverly Hills, CA.

Bone, P.F. (1995), "Word-of-mouth effects on short-term and long-term product judgment", Lournal of Business Research, Vol. 32 No. 3, pp. 213-223.

Brakus, J.J., Schmitt, B.H. and Zarantonello, L. (2009), "Brand experience: what is it? How is it measured? Does it affect loyalty?", Journal of Marketing, Vol. 73 No. 3, pp. 52-68.

Brakus, J.J., Schmitt, B.H. and Zhang, S. (2008), "Experiential attributes and consumer judgments", in Schmitt, B.H. and Rogers D. (Eds), Handbook on Brand and Experience Management. Edward Elgar, Northampton, MA, pp. 174-187.

Browne, M.W. and Cudeck, R. (1993), "Alternative ways of assessing model fit", Testing Structural Equation Models, Sage, Newbury Park, CA, pp. 136-162. 
Carpenter., S., Christensen, N.L., Bartuska, A.M., Brown, A.H., Antonio, C.D., Francis, R., Franklin, J.F., MacMahon, J.A., Noss, R.F., Parsons, D.J., Peterson, C.H., Turner, M.G. and Woodmansee, R.G. (2005), "The report of the Ecological Society of America Committee on the scientific basis for ecosystem management”, Ecological Applications, Vol. 6 No. 3, pp. 665-691.

Carroll, B.A. and Ahuvia, A.C. (2006), "Some antecedents and outcomes of brand love", Market Letters, Vol. 17 No. 2, pp. 79-89.

Cochran, W.G. (1977), Sampling Techniques, 3rd ed., John Wiley \& Sons, New York, NY.

Collins, J. (2011), Good to Great. Why Some Companies Make the Jump and Others Don't, Harper Collins, New York, NY.

Corstjens, M. and Lal, R. (2000), "Building store loyalty through store brands", Lournal of Marketing Research, Vol. 37 No. 3, pp. 281-292.

Davis, F.D. (1989), "Perceived usefulness, perceived ease of use and user acceptance of information technology”, MIS Quarterlv, Vol. 13 No. 3, pp. 319-340.

Davis, F.D. (1993), "User acceptance of information technology: systems characteristics, user perceptions and behaviroal impacts", International Iournal of Man-Machine Studies, Vol. 38 No. 3, pp. 475-487.

Dennis, A.R., Pootheri, S.K. and Natarajan, V.L. (1998), "Lessons form the early adopters of web groupware", Journal of Management Information Systems, Vol. 14 No. 4, pp. 65-86.

DeVellis, R.F. (1991), Scale Development: Theory and Applications (Applied Social Research Methods Series, Vol. 26), Sage, Newbury Park.

Dholakia, U.M., Bagozzi, R.P. and Pearo, L.K. (2003), "A social influence model of consumer participation in network- and small-group-based virtual communities", Intern. I. of Research in Marketing, Vol. 21 No. 3, pp. 241-263.

Diamond, S.S. (2000), "Reference guide on survey research", Reference Manual on Scientific Evidence, 2nd ed., Federal Judicial Centre, Washington, DC, pp. 229-276.

Dichter, E. (1966), "How word of mouth advertising works", Harvard Business Review, Vol. 16 No. 6, pp. 147-166.

Dixon, M., Freeman, K. and Toman, N. (2010), "Stop trying to delight yours customers", Harvard Business Review, Vol. 88 Nos 7/8, pp. 1-8.

Dwyer, C., Hiltz, S. and Passerini, K. (2007), "Trust and privacy concern within social networking sites: a comparison of Facebook \& MySpace", Proceedings of the 13th Americas Conference on Information Systems, Keystone, CO, August 9-12.

Etezadi-Amoli, J. and Farhoomand, A.F. (1996), "A structural model of end user computing satisfaction and user performance", Information \& Management, Vol. 30 No. 2, pp. 65-73.

Flanagin, A.J. and Metzger, M.J. (2001), "Internet use in the contemporary media environment", Human communication Research, Vol. 27 No. 1, pp. 153-181.

Goodman, L.A. (1961), "Snowball sampling", Annals of Mathematical Statistics, Vol. 32 No. 1, pp. 43-58.

Gorn, G.J., Chattopadhyay, A., Yi, T. and Dahl, D.W. (1997), "Effect of color as an executional cue in advertising: they are in the Shade”, Management Science, Vol. 43 No. 10, pp. 1387-1400.

Han, X., Kwortnik, R.J. and Wang, C. (2008), "Service loyalty an integrative model and examination across service contexts", Iournal of Service Research, Vol. 11 No. 1, pp. 22-42.

Hennig-Thurau, T., Gwinner, K.P. and Gremler, D.D. (2004), "Electronic word of mouth via consumer-opinion platform: what motivates consumers to articulate themselves on the internet?", Journal of Interactive Marketing, Vol. 18 No. 1, pp. 38-52.

Hoeffler, S. and Keller, K.L. (2002), "Building brand equity through corporate societal marketing", Iournal of Public Policy \& Marketing, Vol. 21 No. 1, pp. 78-89.
Commercial

value of social networks

593 
JEIM

27,5

594
Hsu, C.L. and Lin, J.C.C. (2008), “Acceptance of blog usage: the roles of technology acceptance, social influence and knowledge sharing motivation", Information \& Management, Vol. 45 No. 1 , pp. 65-74.

Hu, L.T. and Bentler, P.M. (1999), "Cutoff criteria for fit indexes in covariance structure analysis: conventional criteria versus new alternatives", Structural Equation Modeling: A Multidisciplinary Iournal, Vol. 6 No. 1, pp. 1-55.

Hunt, H.K. (1977), "CS/D: overview and future research directions", Conceptualization and Measurement of Customer Satisfaction and Dissatisfaction, in Hunt K.H. (Ed.), Marketing Science Institute, Cambridge, MA, pp. 455-480.

Jevons, C. and Gabbott, M. (2000), "Trust, brand equity and brand reality in internet business relationships: an interdisciplinary approach”, Lournal of Marketing Management, Vol. 16 No. 6, pp. 619-635.

Jonassen, D.H., Peck, K.C. and Wilson, B.G. (1998), "Creating technology-supported learning communities", available at: http://carbon.cudenver.edu/ bwilson/learncomm.html (accessed July 5, 2011).

Keller, K.L. (1987), "Memory factors in advertising: the effect of advertising retrieval cues on brand evaluations", Journal of Consumer-Based Brand Equity, Journal of Marketing, Vol. 57 No. 3, pp. 1-22.

Keller, K.L. (2001), "Building customer-based brand equity: a blueprint for creating strong brands", Marketing Science Institute (MSI), Working Paper No. 01-107.

Ko, H., Cho, C.H. and Roberts, M.S. (2005), "Internet use and gratifications: a structural equation model of interactive advertising", Lournal of Advertising, Vol. 34 No. 2, pp. 57-70.

Kolter, P. (1991), “A frame for marketing image management”, Sloan Manage Rev., Vol. 32 No. 2, pp. 94-104.

Lee, J. and Lee, H. (2010), "The computer-mediated communication network: exploring the linkage between the online community and social capital", New Media \& Societv. Vol. 12 No. 5, pp. 711-727.

Lu, J., Liu, C., Yu, C.S. and Wang, K.L. (2008), "Determinants of accepting wireless mobile data services in China", Information \& Management, Vol. 45 No. 1, pp. 52-64.

McAlexander, J.H., Schouten, J.W. and Koenig, H.F. (2002), “Building brand community”, Journal of Marketing, Vol. 66 No. 1, pp. 38-54.

McKenna, K.Y. and Bargh, J.A. (1999), "Causes and consequences of social interaction on the internet: a conceptual framework”, Media Psvchologv, Vol. 1 No. 3, pp. 249-269.

McQuail, D. (1987), Mass Communication Theory, Sage, Beverly Hills, CA.

Madritch, M.D. and Hunter, M.D. (2002), "Phenotypic diversity influences ecosystem functioning in an OAK Sandhills Community", Institute of Ecology, Vol. 83 No. 8, pp. 2084-2090.

Marsh, H.W. and Hovecar, D. (1985), "Application of confirmatory factor analysis to the study of self-concept: first and higher order factor models and their invariance across groups", Psychological Bulletin, Vol. 97 No. 3, pp. 562-582.

Marsh, H.W., Balla, J.R. and Hau, K.T. (1996), "An evaluation of incremental fit indices: a clarification of mathematical and empirical properties", Advanced Structural Equation Modeling: Issues and Techniques, pp. 562-582.

Meyers-Levy, J. and Peracchio, L.A. (1995), "How the use of color in advertising affects attitudes: the influence of processing motivation and cognitive demands", Lournal of Consumer Research, Vol. 22 No. 2, pp. 121-138.

Mulaik, S.A. (1989), "Evaluation of goodness-of-fit indices for structural equation models", Psvchological Bulletin, Vol. 105 No. 3, pp. 430-445. 
Muñiz, A.M. Jr and O'Guinn, T.C. (2001), "Brand community", Iournal of Consumer Research, Vol. 27 No. 4, pp. 412-432.

Nie, N.H. (2001), "Sociability interpersonal relations, and the internet", American Behavioral Scientist, Vol. 45 No. 3, pp. 420-435.

Oliver, R.L. (1997), Satisfaction: A Behavioral Perspective on the Consumer, McGraw-Hill, Boston, MA.

Perigini, M. and Bagozzi, R.P. (2001), "The role of desires and anticipated emotions in goal-directed behaviors: a model of goal-directed behavior", British Iournal of Social Psychology, Vol. 40, pp. 79-98.

Reicheld, F.F. (1996), The Loyalty Effect: The Hidden Force Behind Growth, Profits, and Lasting Value, Harvard Business School Press, Boston, MA.

Reichheld, F.E. and Sasser, W.E. (1990), "Zero defections: quality comes to services”, Harvard Business Review, Vol. 68 No. 5, pp. 105-111.

Ridings, C.M. and Gefen, D. (2004), "Virtual community attraction: why people hang out online", Journal of Computer-Mediated Communications, Vol. 10 No. 1, available at: http://jcmc. indinan.edu/vol10/issue/ridings_gefen.html (accessed June 28, 2005).

Schmitt, B.H. (1999), Experiential Marketing: How to Get Customer to Sense, Feel, Think, Act, and Relate to Your Company and Brands, The Free Press, New York, NY.

Schultz, D. (2000), "Customer/brand loyalty in an interactive marketplace", Journal of Advertising Research, Vol. 40 No. 3, pp. 41-53.

Singh, J. (1988), “Consumer compliant intention and behavior: a review and prospect”, $\underline{\text { Journal of }}$ Marketing, Vol. 52 No. 1, pp. 93-107.

Stafford, T.F., Stafford, M.R. and Schkade, L.L. (2004), "Determining uses and gratification for the internet”, Decision Science, Vol. 35 No. 2, pp. 259-288.

Sundaram, D.S., Mitra, K. and Webster, C. (1998), "Word of mouth communications: a motivational analysis", Advances in Consumer Research, Vol. 25 No. 1, pp. 527-531.

Swan, J.D. and Oliver, R.L. (1989), "Postpurchase communications by consumers", Lournal of Retailing, Vol. 65, Winter, pp. 516-553.

Taifel, H. (1978), "Interindividual behavior and intergroup behavior", Differentation Between Groups: Studies in the Social Psychology of Intergroup Relations, Academic Press, London, pp. 27-60.

Tsai, S.P. (2005), "Integrated marketing as management of holistic consumer experience", Business Horizons, Vol. 48 No. 5, pp. 431-441.

Venkatesh, V. (2000), "Determinants of perceived ease of use: integrating control, intrinsic motivation, and emotion into the technology acceptance model", Information Svstems Research, Vol. 11 No. 4, pp. 342-365.

Venkatesh, V. and Davis, F.D. (2000), "A theoretical extension of the technology acceptance model: four longitudinal field studies”, Management Science, Vol. 46 No. 2, pp. 186-204.

Veryzer, R.W. Jr and Hutchinson, J.W. (1998), "The influence of unity and prototypicality on aesthetic responses to new product designs", Iournal of Customer Research, Vol. 24 No. 4, pp. 374-394.

Ward, J.C. and Reingen, P.H. (1990), "Sociocognitive analysis of group decision making among consumers", Journal of Consumer Research, Vol. 17 No. 3, pp. 245-263.

Westbrook, R.A. (1987), "Product/consumption-based affective responses and postpurchase processes", Journal of Marketing Research, Vol. 24 No. 3, pp. 258-270.
Commercial

value of social networks

595 
JEIM

27,5

596
Wilson, B. and Ryder, M. (1996), "Learning communities: an alternative to designed instruction", Proceedings of Selected Research and Development National Convention of Association for Educational Research and Technology, Indianapolis, IN, available at: http://carbon. cudenver.edu/ mryder/dlc.html (accessed May 2007).

\section{Further reading}

Aaker, J.L. (1997), "Dimension of brand personality”, Lournal of Marketing Research, Vol. 34 No. 3, pp. 347-356.

Bagozzi, R.P. and Lee, K.H. (2002), "Multiple routes for social influence: the role of compliance, internalization, and social identity", Social Psvchologv Quarterlv, Vol. 65 No. 3, pp. 226-247.

Ellison, N., Steinfield, C. and Lampe, C. (2006), "Spatially bounded online social network and social capital: the role of Facebook", Annual Conference of the international Communication Association, Dresden, June, pp. 1-37.

Lampe, C., Ellison, N. and Steinfield, C. (2007), "Facebook in the crowd: social searching vs social browsing”, In Proc. CSCW 2006 ACM Press, Banff, Alberta, pp. 167-170.

Murphy, S.T. and Zajonc, R.B. (1993), “Affect, cognition and awareness: affective priming with optimal and suboptimal stimulus exposures", Journal of Personality and Social Psychology Vol. 64 No. 5, pp. 723-739.

Owston, R. (1998), Making the Link: Teacher Professional Development on the Internet, Heinemann, Portsmouth, NH.

Saguaro (2000), "Better together: civic engagement in America", available at: www.bettertogether. org/bt_report.pdf (accessed April 2006).

Thomson, M., MacInnis, D.J. and Park, C.W. (2005), "The ties that bind: measuring the strength of consumers' emotional attachments to brands", Journal of Consumer Psychology, Vol. 15 No. 1, pp. 77-91.

Zaichkowsky, J.L. (1985), "Measuring the involvement construct”, Lournal of Consumer Research, Vol. 12 No. 3, pp. 341-352. 
Appendix 1

\begin{tabular}{|c|c|c|c|}
\hline Brand love & BL1 & The brand (of the Facebook page) is a wonderful brand & \\
\hline & BL3 & The brand is totally awesome & \\
\hline & BL4 & The brand brings a cheerful sensation & \\
\hline & BL5 & I love this brand & \\
\hline \multirow[t]{4}{*}{ (2000) and, Venkatesh and Davis (2000) } & PE2 & The page design is easy for me to use & \\
\hline & PE3 & $\begin{array}{l}\text { It is easy to understand the message being communicated } \\
\text { on the Facebook page }\end{array}$ & \\
\hline & & In general, I feel it is easy for me to use this Facebook page & \\
\hline & $\mathrm{PE} 4$ & & \\
\hline & PU3 & $\begin{array}{l}\text { The Facebook page helps me to get to know the } \\
\text { brand better }\end{array}$ & \\
\hline & PU4 & Overall, the Facebook page is useful & \\
\hline Brand experience & BE1 & I have a positive image of this brand's Facebook page & \\
\hline \multirow[t]{7}{*}{ Brakus et al. (2009) } & BE2 & I find this Facebook page very interesting & \\
\hline & BE3 & This Facebook page is appealing to me & \\
\hline & $\mathrm{BE} 4$ & This Facebook page triggers my emotions & \\
\hline & BE5 & I am emotionally attached to this Facebook page & \\
\hline & BE6 & This Facebook page is for a sentimental brand & \\
\hline & BE7 & I have good experiences being a fan of this Facebook page & \\
\hline & BE8 & This Facebook page needs to have hands-on experience & \\
\hline & FL3 & I respond more to this Facebook page compared to others & \\
\hline \multirow{9}{*}{$\begin{array}{l}\text { E-word of mouth } \\
\text { Ha (2002) } \\
\text { Consumer effort } \\
\text { Dixon et al. }(2010)\end{array}$} & EW1 & How likely are you to spread positive word-of-mouth about & \\
\hline & EW2 & I would recommend the brand's Facebook page & \\
\hline & & to my friends & \\
\hline & EW3 & $\begin{array}{l}\text { If my friends were looking for a related topic, I would tell } \\
\text { them to try the brand's Facebook page }\end{array}$ & \\
\hline & & There are many steps to complete the event on the & \\
\hline & CE1 & Facebook page & \\
\hline & CE2 & To enroll the event on the Facebook page takes a lot of time & \\
\hline & CE3 & The events on the Facebook page are complex & Table AI. \\
\hline & CE4 & $\begin{array}{l}\text { Overall, to participate in the event on the Facebook page } \\
\text { takes a lot of time and effort }\end{array}$ & $\begin{array}{r}\text { Explanation of scales } \\
\text { and items }\end{array}$ \\
\hline
\end{tabular}


JEIM

27,5

598

\section{About the authors}

Dr Hsin Chen, $\mathrm{PhD}$, is a Lecturer in the Business Systems Department at the University of Bedfordshire, UK. Her research interests include the adoption and impact of ICTs, small business management, eMarketing, Green IT and the adoption of electronic commerce. Dr Hsin Chen is the corresponding author and can be contacted at: hsin.chen@beds.ac.uk

Dr Anastasia Papazafeiropoulou, PhD, is a Senior Lecturer in the Information Systems and Computing Department at the Brunel University, UK. Her research experience involves the study of diffusion and adoption of electronic commerce, broadband internet, enterprise recourse planning systems (ERPs), customer relationship management systems (CRMs), IP-telephony and mobile TV.

Ta-Kang Chen is an Master Student in the Department of Business Administration from the Soochow University, Taipei, Taiwan. He also works as an IT consultant in United Bank of Switzerland (UBS). His primary research interests include branding management and e-business of social network.

Yanqing Duan, $\mathrm{PhD}$, is a Professor and the Director of Business and Information Systems at the University of Bedfordshire Business School, and a Visiting Professor of China Agricultural University. Her principal research interest has been focused on the use of emerging ICTs in enhancing business performance and supporting decision making.

Dr Hsiu-Wen Liu is an Assistant Professor in the Department of Business Administration from the SooChow University, Taipei, Taiwan. Her research interests include e-commerce, management and marketing.

To purchase reprints of this article please e-mail: reprints@emeraldinsight.com Or visit our web site for further details: www.emeraldinsight.com/reprints 